DOI: https://doi.org/10.15407/techned2020.03.046

\title{
CONTROL OF OVERHEAD CRANE MANIPULATOR HOIST MECHANISM FOR LOWERING BASKET TO THE BATH WITH AGGRESSIVE SOLUTION
}

Journal

Publisher

ISSN

Issue

Pages
Tekhnichna elektrodynamika

Institute of Electrodynamics National Academy of Science of Ukraine 1607-7970 (print), 2218-1903 (online)

No 3, 2020 (May/June)

$46-51$

\section{Authors}

O.I. Tolochko ${ }^{1}$, V.P. Stiazhkin ${ }^{2}$, A. M. Ryzhkov ${ }^{2 \star \star *}$

1- National Technical University of Ukraine Igor Sikorsky Kyiv Polytechnic Institute,

Peremohy ave., 37, Kyiv, 03056, Ukraine,

e-mail: tolochko.ola@gmail.com

2. Institute of Electrodynamics of the National Academy of Sciences of Ukraine,

56 Peremohy Ave., Kyiv, 03057, Ukraine, e-mail: sash1319@gmail.com

* ORCID ID : https://orcid.org/0000-0002-6871-0653

** ORCID ID : https://orcid.org/0000-0003-0602-1112

*** ORCID ID : https://orcid.org/0000-0002-0011-9402

\begin{abstract}
The paper analyses mathematical model for hoisting mechanism of overhead crane manipulator. This crane is expected to operate in waste processing plant in process of deactivation metal. The hoisting mechanism has the form of telescopic column. This column used to submerging basket full of polluted scrap metal in bath with deactivation substance. The model takes into account changes of static torque resistance and motor inertia. The torque resistance change is produced by buoyancy force when basket with load submerging and motor inertia when basket detached from column after sinking to the bath bottom. Results of Simulink modelling showed point to use position control systems. References 7, Figures 7.
\end{abstract}

Key words: crane manipulator, hoisting mechanism, buoyancy force, position control systems. 
Received: 04.09.2019

Accepted: 25.02 .2020

Published: 05.05.2020

\section{References}

1. Stiazhkin V.P., Podeiko P.P., Zaichenko O.A., Havryliuk S.Y., Ryzhkov A.M. Automated control system for electric drives of a overhead crane for installation of metal decontamination. Elektrotekhnycheskye i kompiuternye systemy . 2015. No 19 (95). Pp. 71-74. (Rus)

DOI:

https://doi.org/10.15276/eltecs.19.95.2015.18

2. Ryzhkov O.M., Kondratenko I.P., Tolochko O.I., Stiazhkin V.P. Ways to build an automatic crane manipulator control system. XXIV mizhnarodna konferentsiia z avtomatychnoho upravlinnia Avtomatyka-2017 , Kyiv, Ukraine, September 13-15, 2017. Pp. 104-105. (Ukr)

3. Universal Variable Speed AC Drive for induction and servo motors. Control Techniques. 2012. URL: https://www.galco.com/techdoc/cont/sp2202_um.pdf (Access date 02.08.2019).

4. Komponenty system avtomatyzacyy SV ALJTERA. Svaltera. 2016. URL: http://www.svalter a.ua/upload/iblock/9e7/price_6_sensors_.pdf

(Access date 02.08.2019). (Rus)

5. Jinbo Wu, Zeyu Yang, Donglai Wu. Impedance control of secondary regulated hydraulic crane in the water entry phase. Ocean Engineering. 2018. No 169. Pp. 134-143. DOI: https://d oi.org/10.1016/j.oceaneng.2018.09.025

6. Johansen T.A., Fossen T.I., Sagatun S.I., Nielsen F.G. Wave synchronizing crane control during water entry in offshore moonpool operations-experimental results. IEEE Journal of Oceanic Engineering

2003. Vol. 28(4). Pp 720-728.

DOI:

https://doi.org/10.1109/JOE.2003.819155

7. S.-K. Sul. Control of electric machine drive systems. New Jersey: John Wiley \& Sons, 2011. $424 \mathrm{p}$. 
PDF

@®®॰

This work is licensed under a Creative Commons Attribution-NonCommercial-NoDerivatives $\underline{4.0 \text { International License }}$ 